Al-Fikra: Jurnal Ilmiah Keislaman, Vol. 5, No. 1, Januari-Juni 2006

\title{
HAK-HAK KEWARISAN AHLI WARIS YANG MELAKUKAN TINDAKAN EUTHANASIA
}

\author{
Mohd. Nasir Cholis \\ Fakultas Syariah dan Ilmu Hukum UIN Suska Riau
}

\begin{abstract}
The Rights for Inheritance of Heirs who Commit Euthanasia: Euthanasia is of two categories. Firstly, positive euthanasia, that is, to ease death actively (taisir al-maut al-af'al). Secondly, negative euthanasia which means to ease death without any action at all. According to the law, the positive euthanasia is not permitted and is regarded as a killing, whereas the one who commits such as an action gets no inheritance from the victim. In the case of the negative euthanasia Muslim scholars have different opinions whether it needs treatment or not (patience).
\end{abstract}

Keywords: Inheritance, euthanasia, Law.

\section{Pendahuluan}

Waris merupakan hukum yang mengatur ketentuan pembagian warisan, mengetahui bagian-bagian yang diterima dari harta peninggalan untuk setiap yang berhak. ${ }^{1}$ Hasbi Ash-Shiddieqy menjelaskan bahwa waris adalah hukum yang mengatur siapa-siapa yang mewarisi dan yang tidak mewarisi, bagian penerimaan setiap ahli waris dan tata cara pembagiannya. ${ }^{2}$

Perhatian ulama dalam persoalan waris ini sangat besar. Mereka melakukan pembahasan dalam beberapa sub bagian tertentu mulai dari pengertian, pembagian masing-masing ahli waris, sampai kepada sebab-sebab mendapatkan warisan dan sebab-sebab penghalang mendapatkan warisan. ${ }^{3}$ Ibn Rusyd dalam kitabnya Bidayah al Mujtabid menjelaskan bahwa terdapat beberapa penyebab seseorang terhalang mendapatkan warisan, di antaranya melakukan pembunuhan. ${ }^{4}$ Disebutkan bahwa orang yang membunuh tidak mendapatkan warisan sama sekali dari orang yang dibunuhnya. Pendapat ini berdasarkan kepada sabda Nabi Muhammad SAW yang mengatakan Tiada bak bagi si pembunub mempusakai sedikitpun. (HR. al Nasa'i)

Terdapat perbedaan pendapat di antara para ulama mengenai pembunuhan yang dimaksud. Sebagian ulama memisahkan antara pembunuhan yang disengaja (qatlu al 'amdi) dengan pembunuhan yang tidak

${ }^{1}$ Muhammad Syarbin al Khatib, Mughni al Mubtaj, Juz. 3, (Kairo : Mustafa al Baby al Halaby, 1995) hlm. 3

2T.M. Hasby Ash-Shiddieqy, Fiqh Mawaris, (Yogyakarta: Mudah, tt) hlm. 8

${ }^{3}$ Pembahasan mengenai warisan ini banyak dikaji dalam berbagai kitab, seperti Wahbah al Zuhaili dalam kitabnya Fiqhu al Islam wa 'Adillatubu, Sayyid Sabiq dalam kitab Figh al Sunnah dan juga Ibn Rusyd dalam kitan Bidayah al Mujtabid

"Ibnu Rusyd, Bidayah al Mujtabid, (Semarang : al Syifa), hlm. 514 
Al-Fikra: Jurnal Ilmiah Keislaman, Vol. 5, No. 1, Januari-Juni 2006

disengaja (qatlu ghairi al amdi). Mereka berpendapat bahwa pada pembunuhan yang disengaja membunuh tidak memperoleh sesuatu apapun, artinya yang bersangkutan tidak mendapatkan warisan. Sedangkan pada pembunuhan yang tidak disengaja, pembunuh mendapatkan warisan sama sekali, kecuali terhadap diyat harta. Pendapat seperti ini dikemukakan oleh Iman Malik dan pengikutnya. 5 Sementara itu ulama lain memisahkan pula antara kesengajaan yanga terjadi pembunuhan karena perkara yang wajib dan yang bukan wajib, seperti jika orang tersebut membunuh karena harus menegakkan hukuman budud.

Perbedaan pendapat di atas terjadi akibat adanya pertentangan antara aturan pokok syara' dalam masalah ini dengan tinjauan kemaslahatan yang sering dimuat dan dibicarakan dalam konteks maqasid al syariah. Tinjauan kemaslahatan menghendaki agar pembunuhan tersebut tidak mewarisi sama sekali supaya orang banyak tidak mengambil warisan dengan jalan (zadd li al zariah) membunuh dan semacamnya. Kebijakan-kebijakan hukum seperti ini sering dikemukakan ulama dalam rangka menutup jalan dan menolak terjadinya mafsadah dalam kehidupan masyarakat.

Terjadi fenomena baru di tengah masyarakat dewasa ini tentang mengakhiri hidup seseorang yang tidak mungkin bisa sembuh. Perbuatan ini dikenal dengan istilah euthanasia, yakni tindakan memudahkan kematian seseorang dengan sengaja tanpa merasakan sakit, karena kasih sayang dengan tujuan meringankan penderitaan si sakit, baik dengan cara positif maupun negatif. 6

Fenomena ini membuat penulis tertarik untuk mengkaji antara sebabsebab penghalang mendapatkan warisan (sebab pembunuhan) kaitannya dengan tindakan euthanasia. Apakah tindakan euthanasia yang dilakukan keluarga atau ahli warisnya menjadi penyebab seseorang terhalang mendapatkan warisan karena dikaitkan dengan pembunuhan sebagai penyebab terhalangnya mendapat warisan.

\section{Euthanasia dalam Perspektif Islam}

Istilah euthanasia berasal dari bahasa Yunani, yaitu eu dan thanatos. Kata eu berarti indah, bagus, terhormat, atau graefully and with dignity, sedangkan thanatos berarti mati. Jadi secara etimologi euthanasia dapat diartikan sebagai mati dengan baik (a good death). 7

Dalam Kamus Besar Bahasa Indonesia disebutkan, bahwa euthanasia secara etimologi berarti mati gampang atau mati mudah. Sedangkan secara terminologi euthanasia berarti tindakan mengakhiri dengan sengaja kehidupan

${ }^{5}$ Ibid

'Yusuf al Qardhawi, Hadya al Islam Fatawa al Mu'asharah, terj. (Jakarta : Gema Insani Press, 1998) hlm. 749

${ }^{7}$ Petrus Yoyo Karmadi, Euthanasia dalam Perspektif Hak Azasi Manusia, (Yogyakarta: Media Presindo, 2001), hlm. 25-26 
manusia yang sakit keras atau luka parah dengan kematian yang tenang dan mudah atas dasar pertimbangan kemanusiaan. ${ }^{8}$

Meminjam istilah Plato, seorang filosof kenamaan (50-20 SM), euthanasia merupakan mati dengan tenang dan baik. Sementara dalam analisis St. Thomas euthanasia adalah bentuk pengakhiran hidup yang sengsara secara bebas dan dengan berhenti makan atau dengan minum racun yang membinasakan. Yusuf al Qardhawi menyebutkan bahwa euthanasia ialah tindakan memudahkan kematian seseorang dengan sengaja tanpa merasakan sakit, karena kasih sayang, dengan tujuan meringankan penderitaan si sakit.?

Di dalam Ensiklopedi Hukum Islam disebutkan bahwa euthanasia adalah tindakan mengakhiri dengan sengaja kehidupan seseorang agar ia terbebaskan dari kesengsaraan yang diderita. ${ }^{10}$ Pendapat lain mengatakan bahwa euthanasia adalah mati yang baik tanpa melalui proses kematian dengan rasa sakit atau penderitaan yang berlarut-larut. ${ }^{11}$

Dari beberapa definisi di atas, dapat disimpulkan bahwa euthanasia merupakan cara mengakhiri kehidupan manusia atau mempercepat kematian, yang tujuan utamanya adalah untuk memberikan rasa kasih kepada si penderita. Perbedaan yang prinsip antara bunuh diri, ${ }^{12}$ dengan euthanasia adalah bahwa bunuh diri merupakan tindakan yang dilakukan sendiri oleh pelakunya, baik dengan cara pelan seperti meneguk minuman yang sudah dicampur dengan racun, maupun dengan cara keras dan mengerikan, seperti menjatuhkan diri dari ketinggian yang menurut adat dapat menyebabkan kematian, sedangkan euthanasia juga merupakan usaha mempercepat kematian dengan difasilitasi oleh orang lain, seperti dokter menyuntikkan obat yang mematikan atau tidak melakukan tindakan yang pada saat itu dipandang perlu untuk dilakukan oleh seorang dokter atau orang lain, dengan alasan atas permintaan si pasien atau dipertegas oleh izin dari keluarga atas dasar pertimbangan kemanusiaan. ${ }^{13}$ Pada euthanasia ini biasanya kematian dilakukan

${ }^{8}$ Departemen Pendidikan dan Kebudayaan, Kamus Besar Bahasa Indonesia, (Jakarta: Balai Pustaka, 1989), hlm., 138.

'Yusuf al Qardawi, Fatwa-Fatwa Kontemporer, alih bahasa: Drs. As'ad Yasin Jilid II, (Jakarta: Gema Insani Pers, 1995) hlm., 749.

${ }^{10}$ Tindakan ini diberikan/dilakukan terhadap penderita penyakit yang tidak mempunyai harapan untuk disembuhkan. Ensiklopedi Hukum Islam, (Jakarta: Ichtiar Baru Van Hoeve, 1996), hlm., 290.

${ }^{11}$ Syamsul Arifin, Menurut Pandangan Islam; Euthanasia Dilarang, Kiblat No. 18 th XXVII 1 Pebruari, 1981, hlm., 93, dikutip dari Huzaimah T. Yanggo, Masail Fiqhiyyah, dalam Edisi Kajian Hukum Islam Kontemporer, (Bandung: Angkasa, 2005), hlm., 104.

${ }^{12}$ Bunuh diri diartikan dengan kesengajaan mematikan diri sendiri. Departemen Pendidikan dan Kebudayaan, Kamus... , hlm. 138. Pengertian ini dapat dpertegas bahwa usaha-usaha yang dilakukan untuk sampainya seseorang kepada kematian murni merupakan usaha pribadinya tanpa pertolongan orang lain.

${ }^{13}$ Sesungguhnya euthanasia dengan alasan dan mengatasnamakan kemanusiaan akan dapat menimbulkan konotasi negatif terhadap ketentuan Allah yang Maha Kasih. Sebab, dengan dalih kemanusiaan seolah-olah Tuhan dapat dianggap tidak manusiawi dalam 
dengan cara yang sangat lunak tidak seperti pada sebagian yang terjadi pada bunuh diri.

Dalam perspektif medis, terdapat dua tipe euthanasia yang dikenal dalam dunia kedokteran, yaitu euthanasia positif (taisir al maut al af'al), kemudian euthanasia negatif (taisir al maut al munfa'il).

Euthanasia positif berarti tindakan seorang dokter untuk mempercepat kematian (pasien) dengan memberikan suntikan ke dalam tubuh si pasien tersebut. Dengan kata lain, bahwa tindakan tersebut merupakan tindakan memudahkan kematian seorang pasien yang menjadikan dokter sebagai eksekutor dengan alasan kasih sayang dan kemanusiaan, dengan menggunakan instrumen atau alat tertentu. ${ }^{14}$

Sedangkan euthanasia negatif merupakan tindakan dokter, ${ }^{15}$ berupa tindakan menghentikan segala bentuk pengobatan, disebabkan si pasien mengalami sakit yang teramat keras, yang secara medis tidak mungkin dapat disembuhkan. Alasan yang sering diberikan adalah karena si pasien tidak mampu lagi dari segi financial untuk membiayai pengobatan yang cukup tinggi, sedangkan pada saat itu fungsi pengobatan yang diberikan dipandang tidak efektif lagi. Ada lagi upaya lain yang dipandang sebagai euthanasia negatif yaitu upaya dokter menghentikan pengobatan terhadap pasien yang menurut penelitian medis masih mungkin untuk disembuhkan. Kebanyakan alasan yang dikemukakan adalah karena pasien tidak mempunyai biaya. ${ }^{16}$

Syari'at Islam menjelaskan bahwa segala daya upaya atau perbuatan yang berakibat matinya seseorang, baik yang disengaja atau tidak disengaja, tidak dapat dibenarkan dan merupakan perbuatan terlarang. Berkaitan dengan euthanasia, untuk menjelaskan hukumnya, maka penulis membagi kepada dua kelompok. Pertama. euthanasia positif, yaitu memudahkan kematian secara aktif (taisir al- maut al-af'al), seperti tindakan dokter memberikan obat dengan over dosis, kepada pasien yang sering pingsan atau kepada pasien yang terlalu lama menahan sakit yang bersangatan dan mencabut alat bantu pernafasan dari si pasien; kedua, euthanasia negatif, yaitu memudahkan kematian dengan tidak melakukan tindakan sama sekali, seperti dokter menahan tidak memberikan obat kepada pasien. Hal ini didasarkan pada keyakinan dokter bahwa pengobatan yang akan diberikan tidak ada gunanya dan tidak akan memberikan efek kepada pasien tersebut. ${ }^{17}$

memberikan cobaannya kepada hamba-hambanya. Padahal sesungguhnya Allah SWT memberikan ujian kepada manusia di dasarkan atas kasih sayang dan rahmat-Nya yang paling dalam, bukan dilandaskan kepada kebencian

${ }^{14}$ Yusuf al Qardawi, Fatwa-fatwa..., hlm. 749

${ }^{15}$ Sesunggunya tindakan untuk terjadinya euthanasia, bukan saja semata-mata hanya dapat dilakukan oleh seorang dokter atau tim medis lainnya, tetapi juga dapat dilakukan oleh yang bukan dokter, seperti keluarga dan sebagainya.

16 Ensik.lopedi..., hlm. 290.

17 Yusuf al- Qardawi, Fatwa-fatwa..., hlm. 749 dan 754. 
Tindakan menyegerakan kematian dalam kasus pertama di atas, jelas tidak diperkenankan oleh hukum Islam. Sebab Dokter melakukan tindakan aktif dengan tujuan membunuh si pasien, maka dalam hal ini sama dengan membunuh secara sengaja seperti membunuh orang lain dengan benda keras atau benda lainnya, meskipun berbeda motivasi yang mendorongnya, seperti alasan kasih sayang.

Memudahkan kematian secara aktif, seperti kasus di atas, tidak dapat lepas dari kategori pembunuhan meskipun yang mendorongnya itu rasa kasihan kepada si sakit atau untuk meringankan penderitaannya, karena dokter tidaklah lebih pengasih dan penyayang dari Dzatnya. ${ }^{18}$ Al- Qur'an sebagai risalah Allah, telah menegaskan dalam salah satu ayat-Nya: "Dan janganlah kamu membunuh dirimu, sesungguhnya Allah adalab Maha penyayang kepadamu. Dan barang siapa berbuat demikian dengan melanggar dan berbuat aniaya, maka Kami kelak akan memasukkannya ke dalam neraka" (QS. An Nisa' : 28-29). ${ }^{19}$

Ayat di atas, merupakan dalil umum untuk larangan setiap kasus pembunuhan, baik bunuh diri maupun mempercepat kematian dengan alasan kasih sayang tersebut. Sebab, Amru bin Ash seperti yang dikutip oleh M. Ali Hassan memahami ayat tersebut dengan bunuh diri, akan tetapi Ibn Abbas dan kebanyakan ahli tafsir lebih memahaminya dengan saling membunuh. ${ }^{20}$

Makna penafsiran kedua di atas, menurut penulis dapat dipahami sebagai dalil pelarangan euthanasia tersebut. Sebab, saling membunuh juga dapat diartikan dengan melakukan tindakan medis oleh seorang dokter kepada pasien yang sedang sakit keras, dan di sisi lain si pasien sudah tidak kuasa lagi menahan penderitaan tersebut. Seorang dokter dapat dikatakan membunuh pasien dengan memberikan obat dalam skala tinggi/ over dosis, yang menurut perkiraan dunia kesehatan besar kemunginan akan menimbulkan kematian. Perbedaan secara prinsip dengan pembunuhan sengaja hanya terletak pada kehendak. Pembunuhan yang dilakukan seseorang kepada orang lain kehendaknya murni merupakan keinginan sang pembunuh, tetapi pada kasus euthanasia, keinginan terjadinya kematian memang merupakan keinginan penuh dari si pasien atau keluarga pasien.

Perbedaan lain terletak pada motif pembunuhan. Pada kasus pembunuhan biasa, yang menjadi motif utamanya adalah kebencian yang berujung kepada kekerasan dan tindakan pendzaliman, sedangkan pada euthanasia yang menjadi motivnya adalah kasih sayang.

Euthanasia aktif dapat dikategorikan kepada pembunuhan adalah menghentikan alat bantu pernafasan bagi pasien yang memang sangat tergantung dan membutuhkan alat bantu tersebut, sedangkan pasien pada saat itu masih sangat dimungkinkan kehidupannya. Tindakan menghentikan

${ }^{18}$ Ibid, hlm., 751.

${ }^{19}$ Mujamma' al- Malik Fahd li Thiba'at al- Mushaf as- Syarif Madinah Munawwarah, alQur'an dan Terjemahan, 1418, hlm., 128.

20 M.Ali Hassan, Masail Fiqhiyah al-Haditsah..., hlm., 44. 
peralatan susungguhnya tidak dapat dikategorikan kepada euthanasia pasif, sebab menghentikan berarti melakukan tindakan. Berbeda halnya, jika penghentian tersebut menurut dugaan kuat dokter dianggap sudah mati, atau dihukumi sudah mati, karena jaringan otak atau sum-sum yang dengannya seseorang dapat hidup dan merasakan sesuatu yang telah rusak.

Tindakan di atas dibenarkan oleh syara', tidak terlarang. Lebih-lebih peralatan-peralatan tersebut hanya dipergunakan sekedar untuk kehidupan yang lahir, yang tampak dalam pernafasan dan peredaran darah denyut nadi saja, padahal dilihat dari segi aktivitas maka si sakit itu sudah seperti orang mati, tidak responsif. ${ }^{21}$

Dengan demikian, jelas bahwa tindakan euthanasia dalam konteks ini tidak dapat dibenarkan, dan bahkan sang dokter dan keluarga pasien yang merelakan perbuatan tersebut, dapat saja dikategorikan pembunuh, walaupun tidak secara langsung. Dengan memberikan restu terhadap terjadinya tindakan tersebut, sama artinya membunuh.

Sesungguhnya inti persoalan pada euthanasia bukan saja terletak pada tindakannya semata, tetapi hal yang juga subtantif adalah tentang hukum berusaha berobat bagi seorang yang sakit. Artinya, apakah wajib atau tidak berobat bagi seorang pasien dalam kondisi apapun. Tentang masalah ini jumhur fuqaha berpendapat bahwa berobat atau mengobati penyakit tidak wajib hukumnya. Bahkan mereka menegaskan, mengobati atau berobat hukumnya mubah. Dalam hal ini hanya sedikit sekali golongan yang mengatakan bahwa berobat hukumnya adalah wajib, seperti sahabat-sahabat Imam Syafi'i dan Imam Ahmad. ${ }^{22}$

Alasan lain juga banyak ditemukan para sahabat dan tabi'in yang tidak berobat ketika mereka sakit, bahkan di antara mereka ada yang memilih untuk sakit, seperti Ubai bin Ka'ab dan Abu Dzar. Namun demikian, tidak ada satu orang pun yang mencela dan menegurnya. ${ }^{23}$

Sementara itu Yusuf al- Qardawi menjelaskan bahwa jika si pasien masih ada kemungkinan untuk dapat disembuhkan maka di sini wajib hukumnya untuk diobati. Menghentikan pemberian obat merupakan tindakan yang menyalahi ketentuan Allah SW'T. Dengan demikian, apabila euthanasia dilakukan jelas menyalahi hukum syara'. Tetapi ia menegaskan, bahwa apabila menurut medis tidak mungkin lagi disembuhkan, padahal ia dalam keadaan

${ }^{21}$ Bahkan lebih lanjut Yusuf al- Qardawi menegaskan bahwa tindakan membiarkan si sakit dalam kondisi tersebut, hanya akan menghabiskan dana yang banyak bahkan tidak terbatas. Selain itu juga menghalangi penggunaan alat-alat tersebut bagi orang lain yang membutuhkannya dan masih dapat memperoleh mamfaat dari alat tersebut. Di sisi lain, penderita yang sudah tidak dapat merasakan apa-apa itu hanya menjadikan sanak keluarganya selalu dalam keadaan sedih dan menderita, yang mungkin sampai bertahun-tahun lamanya. Lihat lebih lanjut Yusuf al- Qardawi, Fatwa-fatwa..., hlm., 754-755.

22 Ibn Taimiyah, al- Fatawa Kubra, Juz IV, (Kairo: Mathba'ah al- Kurdistan al- Ilmiyyah, tt), hlm., 260.

${ }^{23}$ Yusuf al- Qardawi, Fatwa-fatwa..., hlm., 752. 
sakit yang luar biasa, maka melanjutkan pengobatan tidaklah wajib dan tidak mustahab, dan bahkan yang wajib adalah tindakan menghentikan pengobatan. ${ }^{24}$

Menurut penulis, mengakhiri hidup seseorang yang sakit atau melakukan euthanasia dalam kedua jenis di atas, merupakan tindakan mendahului ketentuan Allah SWT. Allah SWT telah menentukan batas akhir usia bagi manusia. Menurut penulis, persoalan hidup dan mati manusia merupakan urusan pencipta yang tidak dapat diuji secara ilmiah melalui pengetahun manusia, kendatipun memang sebagian dari hipotesis medis tersebut kebetulan terbukti secara factual dan meyakinkan.

Argument lain, sebagaimana disebutkan dalam salah satu hadis (berikut populer dengan istilah kaedah fighiyyah) disebutkan bahwa manusia tidak boleh menciptakan kemudlaratan untuk dirinya dan juga untuk orang lain. Kaidah dimaksud adalah: la darara wa la dirara ${ }^{25}$

Menurut ajaran Islam yang berhak menghidup dan mematikan manusia itu hanya Allah SWT. Manusia tidak mempunyai hak atau kewenangan untuk memberi hidup atau mematikannya. Tindakan tidak bertindak menurut hemat penulis merupakan sikap yang keliru baik bagi pasien ataun keluarga juga keliru bagi dokter yang melaksanakannya. ${ }^{26}$

Dalam menghadapi berbagai persoalan, manusia tetap diperintahkan untuk selalu berusaha. Itulah rahasianya, mengapa manusia tidak pernah dapat mengetahui apa yang akan terjadi di masa akan datang. Dengan demikian, manusia diperintahkan untuk tetap bersabar dan berusaha sampai Allah SW'T memberikan kejelasannya.

Melakukan euthanasia dapat diartikan sebagai upaya mengebiri hak Allah SW'T yang sudah menjadi ketetapanNya. Euthanasia juga merupakan wujud ketidakmampuan manusia menghadapi ujian Tuhan dan mudah menyerah pada sebuah keadaan, padahal Tuhan memerintahkan manusia untuk selalu berusaha dan berikhtiar. hlm. 27

\footnotetext{
${ }^{24}$ Ibid.,

${ }^{25}$ Imam Masbukin, Qawa’id al- Fiqhiyyah, (Jakarta: PT. Raja Grafindo Persada, 2001),
}

${ }^{26}$ Di dunia medis, melakukan euthanasia bagi para dokter dianggap sebuah persoalan yang sangat sulit. Kendatipun di satu sisi dengan dalih dan alasan kemanusiaan hal itu dapat saja dibenarkan, dan merupakan hak bagi pasien, sesuai dengan deklarasi Lisboa tahun 1981. Kendatipun demikian seorang dokter tidak dibenarkan melakukan upaya aktif untuk memenuhi keinginan pasien tersebut. Hal ini disebabkan oleh dua hal: Pertama, karena adanya persoalan yang berkaitan dengan kode etik kedokteran, di satu pihak dokter dituntut untuk membantu meringankan penderitaan pasien, akan tetapi di pihak lain menghilangkan nyawa orang merupakan penggaran terhadap kode etik itu sendiri. Kedua, tindakan menghilangkan nyawa orang lain dalam perundang-undangan merupakan tindakan pidana yang melanggar ndang-undang. Lihat, Ensiklopedi Hukum Islam, (Jakarta: Ichtiar Baru Van Hoeve, 1996), hlm. 290. 
Al-Fikra: Jurnal Ilmiah Keislaman, Vol. 5, No. 1, Januari-Juni 2006

\section{Hak-Hak Kewarisan Ahli Waris yang Melakukan Tindakan Euthanasia}

Sebagaimana telah dipaparkan sebelumnya bahwa euthanasia terbagi kepada dua macam, pertama, euthanasia positif yakni melakukan tindakan aktif yang tujuannya membunuh si sakit dan mempercepat kematiannya melalui pemberian obat secara overdosis. Euthanasia dalam tataran seperti ini disepakat oleh ahli fiqh sebagai tindakan pembunuhan. Karenanya, bila seorang ahli waris melakukan tindakan euthanasia seperti di atas, misalnya dengan melakukan tindakan sesuatu kepada si sakit (pewaris), sehingga dengan tindakan seperti itu si sakit meninggal dunia, maka ahli waris yang bersangkutan terhalang mendapatkan harta warisan.

Perbuatan seperti tersebut di atas termasuk kategori pembunuhan meskipun ahli waris terdorong melakukannya atas dasar rasa kasihan kepada si sakit dan untuk meringankan penderitaanya. Karena bagaimanapun, ahli waris atau pihak medis, tidak lebih pengasih dan lebih penyanyang dari Zat Yang Menciptakannya. Karena itu serahkanlah kepada Allah SWT, karena Dialah yang memberikan kehidupan kepada manusia dan yang mencabutnya apabila telah tiba ajal yang telah ditetapkan-Nya.

Argumentasi untuk menjawab terhalangnya ahli waris pelaku euthansia positif mendapatkan warisan adalah hadis dari Nabi Muhammad SAW yang ekplisit mengatakan: Tiada hak bagi si pembunub mempusakai sedikitpun. (HR. al Nasa'i)

Berdasarkan hadis Nabi riwayat al Nasa'i di atas, seorang pembunuh tidak bisa mempusakai sedikitpun harta warisan dari orang yang dibunuhnya.

Para ulama telah menyepakati bahwa pembunuhan merupakan salah satu penghalang seseorang mendapatkan warisan, baik para pelaku pembunuhan tersebut mendapatkan sangsi qishas atau kafarat.

Ibn Rusyd mengatakan bahwa para ulama secara jelas berpendapat bahwa pembunuhan menjadi pengalang seseorang untuk mewarisi harta orang yang dibunuhnya. Kemudian Ibnu Rusyd memaparkan empat pendapat ulama mengenai hal ini termasuk pengklasifikasian yang mereka berikan: Pertama, bahwa orang yang membunuh tidak mewarisi sama sekali orang yang dibunuhnya, kedua, bahwa orang yang membunuh itu mewarisi, namun kata Ibnu Rusyd, fuqaha' yang berpendapat seperti ini sangat sedikit sekali, ketiga, mengadakan pemisahan antara membunuh dengan tidak sengaja atau tersalah dengan membunuh disengaja. Fuqaha' golongan ini, kata Ibnu Rusyd, mengadakan pemisahan bahwa pembunuh yang tersalah atau tidak disengaja dapat mewarisi harta orang yang dibunuhnya secara tersalah tersebut, sedangkan pembunuhan yang disengaja tidak dapat mewairis orang yang dibunuhnya, keempat, dengan memisahkan antara dengan kesengajaan yang 
terjadi pembunuhan karena perkara yang wajib dan yang bukan wajib, seperti jika orang tersebut membunuh karena harus menegakkan hukuman budud. ${ }^{27}$

Mazhab Syafiiyah, seperti dikutip Fatchur Rahman, memiliki pendapat yang memutlakkan seluruh tindakan pembunuhan menghalangi seseorang mewarisi orang yang dibunuhnya, baik langsung maupun tidak langsung, baik karena ada alasan maupun tidak. ${ }^{28}$ Oleh karena itu pembunuh yang harus diqishas tidak dapat mempusakai harta orang yang dibunuhnya. Hakim yang menjatuhkan hukuman mati tidak dapat mempusakai harta orang yang diperintahkan untuk dibunuh, algojo yang menjalankan tugas hukuman mati, tidak dapat mempusakai orang yang dibunuhnya, tentara yang diperintahkan menembak keluarganya yang memberontak tidak dapat mewarisi harta keluarga yang dibunuhnya itu. ${ }^{29}$ Pendapat kelompok Syafiiyah di atas, diambil berdasarkan pemahaman terhadap makna hadis tentang 'pembunub tidak mewarisi harta orang yang dibunubnya' secara mutlak.

Berdasarkan pendapat ulama di atas dapat diketahui bahwa pembunuhan yang dilakukan dengan sengaja, sepakat para ulama bahwa pembunuhnya tidak berhak mewarisi harta dari orang yang dibunuhnya. Dengan demikian seorang ahli waris palaku euthanasia positif, dimana termasuk ke dalam mengakhiri hidup seseorang dengan sengaja, juga tidak bisa mewarisi karena termasuk kedalam golongan tindakan pembunuhan yang disengaja.

Argumentasi lain sebagai penguat terhalangnya si pembunuh mendapatkan harta orang yang dibunuhnya, adalah qaidah fiqhiyah yang mengatakan: "Barang siapa yang mempercepat seseuatu sebelum masanya dibukum haram menggunakannya."30

Ini berarti bahwa seorang ahli waris yang membunuh ahli waris yang membunuh dan mengusahakan membunuh orang yang bakal mewariskan harta peninggalan kepadanya dengan maksud mempercepat mendapatkan harta warisan, maka pembunuh terhalang mewarisi harta orang yang dibunuhnya.

Bentuk euthansia yang kedua adalah euthanasia negatif (pasif) yakni mengakhiri hidup si sakit dengan cara tidak menggunakan alat atau langkahlangkah aktif untuk mengakhiri kehidupan si sakit, tetapi ia hanya dibiarkan tanpa diberi pengobatan untuk memperpanjang hayatnya, seperti penderita

${ }^{27}$ Ibnu Rusyd mengklasifikasikan bentuk-bentuk pembunuhan di atas secara sederhana tanpa menyebutkan pendapat ulama tersebut secara rinci alasan dan dalil masingmasing ulama tersebut. Namun demikian empat bentuk klasifikasi di atas setidak-tidak mampu merepresentasikan klasifikasi pembunuhan yang berimplikasi terhadap hak seseorang dalam mewarisi harta orang yang dibunuhnya. Baca: Ibn Rusyd, Bidayah al Mujtabid, juz. 3 (Semarang: Asy Syifa', 1990) hlm. 514.

${ }^{28}$ Fathurrahman, Ilmu Waris.... hlm.

${ }^{29}$ Fathur Rahman, Ibid.

${ }^{30}$ Mukhtar Yahya dan Fatchurrahman, Dasar-dasar Pembinaan Hukum Islam, (Bandung: Al Ma'arif, 1986) hlm. 547 
kanker yang sudah kritis, orang sakit yang sudah dalam keadaan koma disebabkan benturan pada bagian kepalanya atau terkena semacam penyakit pada otak yang tidak ada harapan untuk sembuh, atau orang yang terkena serangan penyakit paru-paru yang jika tidak diobati, padahal masib ada kemungkinan untuk diobati akan dapat mematikan penderita, dalam hal ini jika pengobatan terhadapnya dihentikan akan dapat mempercepat kematiannya. Euthansia dalam tataran seperti ini menjadi perdebatan di kalangan ahli fiqh, apakah termasuk ke dalam kelompok pembunuhan atau tidak, dimana nantinya berimplikasi terhadap hak warisan para ahli warisnya.

Para ulama berbeda pendapat tentang persoalan ini karena berbedanya pendapat mereka tentang kedudukan hukum berobat dari suatu penyakit. Ibn Taimiyah, dalam kitabnya al Fatawa al Kubra, memaparkan bahwa kalangan Imam dari jumhur fuqaha' tidak mewajibkan hukum berobat. Mereka hanya memposisikan berobat itu pada tataran mubab31 saja. Hanya segolongan kecil saja yang mewajibkan berobat sebagaimana dikemukan oleh sahabat-sahabat Imam Syafii dan Imam Ahmad. ${ }^{32}$

Perbedaan pendapat ulama mengenai status hukum berobat bagi seseorang yang sedang sakit akan berpengaruh kepada status hukum tindakan euthanasia secara negatif (pasif). Sebab euthanasia negatif hanya berupa tindakan menghentikan pengobatan, sehingga dengan menghentikan pengobatan tersebut sang pasien mengalami kematian.

Tidak saja pada status hukum berobat, tentang mengenai mana yang lebih afdhal berobat atau tidak, ternyata diantara para ulama ada yang berpendapat bahwa tidak berobat (bersabar) lebih utama. Pendapat ini mereka dasarkan pada hadis Rasululullah SAW dari Ibn Abbas tentang seorang wanita yang ditimpa epilepsi. Wanita itu meminta pendapat kepada Rasululullah SAW, kemudian beliau menjawab: "Jika engkau mau bersabar (maka bersabarlab), engkau akan mendapatkan surga, dan jika engkau mau akan saya doakan kepada Allab agar Dia menyembubkanmu. "Wanita itu menjawab aku akan bersabar." Sebenarnya saya tadi ingin dibilangkan penyakit saya. Oleh karena itu doakanlah kepada Allah agar saya tidak diminta dibilangkan penyakit saya. Lalu Nabi mendoakan orang itu agar tidak meminta dibilangkan penyakitnya." 33

${ }^{31}$ Mubah yaitu suatu perbuatan yang bila dikerjakan, orang yang mengerjakannya mendapatkan pahala, dan bila ditinggalkan, orang yang meninggalkannya tidak menerima dosa. Suatu perbuatan dikatakan mubah diketahui dengan beberapa jalan, diantaranya perbuatan tersebut ditetapkan secara tegas kebolehannya oleh syara'. Misalnya Syari mengatakan dengan perkataan: la junaba, la haraja, la itsana, (tidak mengapa, tidak halangan, tidak berdosa). Seperti firman Allah SW'T: "Dan tidak balangan bagi kamu meminang wanitawanita itu dengan sindiran yang baik..." (QS. al Baqarah [2]: 235)

Makna mubah bisa juga diketahui suatu statmen Syar'i yang memerintahkan melakukan sesuatu tetap ada qarinah yang menunjukkan bahwa perintah itu hanya untuk mubah saja. Lebih jelas baca: Mukhtar Yahya dan Fatchurrahman, Ibid., hlm. 144.

32Ibnu Taimiyyah, Al-Fatawa..., hlm. 260

${ }^{33}$ Hadis ini dimuant oleh Al Bukhari dalam kitabya, Sabih al Bukhari, pada Bab tentang Sakit. 
Al-Fikra: Jurnal Ilmiah Keislaman, Vol. 5, No. 1, Januari-Juni 2006

Hadis di atas secara eksplisit memberikan jawaban yang jelas, bahwa seseorang yang sakit, lebih utama untuk bersabar dan tidak berobat, karena balasan bagi orang yang bersabar dengan sakitnya dan tidak berobat mendapat balasan surga dari Allah.

Disamping hadis di atas sebagai argumentasi pendukung tidak berobat adalah lebih baik, ulama juga mengambil bujjah dari sikap kalangan sahabat yang tidak berobat ketika mereka sakit. Ibnu Taimiyah menginformasikan bahwa Unay bin Ka'ab dan Abu Zar r.a. memilih untuk tidak berobat ketika mereka sakit. ${ }^{34}$

Berdasarkan pendapat ulama yang mengatakan bahwa tidak berobat lebih utama dan bersabar tehadap sakit yang dideritanya akan mendapatkan surga membuat hukum berobat tidak wajib. Atas pendapat ini maka dapat disimpulkan bahwa pelaku euthanasia negatif, yakni menghentikan pengobatan terhadap si sakit yang tidak diharapkan sembuhnya, tidak termasuk ke dalam kelompok pembunuhan. Karenanya ahli waris yang melakukan tindakan euthanasia negatif tersebut tidak terhalang mendapat warisan dari orang yang dilakukan tindakan euthanasia terhadapnya.

Imam al Gahazali ketika membicarakan tema tentang al tawakal. ${ }^{35}$ memberikan pembahasan panjang lebar mengenai eksistensi tawakal yang berimplikasi kepada hukum berobat dari sakit. Imam al Ghazali mengatakan tida benar bahwa tawakkal adalah meninggalkan usaha-usaha yang bersifat badaniah. Beliau menjelaskan mengenai empat macam makna tawakal, yakni; pertama, berusaha memperoleh sesuatu yang dapat memberikan manfaat kepadanya, kedua, berusaha memelihara sesuatu yang dimilikinya dari sesuatu yang tidak bermanfaat; ketiga, berusaha menolak dan menghindari diri dari halhal yang menimbulkan mudhorat; dan keempat, berusaha menghilangkan mudharat yang menimpa dirinya.

Implikasi pendapat Imam al Ghazali di atas adalah bahwa berobat lebih utama daripada tidak berobat, sebab tawakkal mestilah suatu untuk menghindari diri dari hal-hal yang menimbulkan mudharat. ${ }^{36}$

Bila berangkat dari pemahaman Imam al Ghazali di atas, maka tindakan euthanasia negatif yang tidak memberikan obat terhadap si sakit merupakan

${ }^{34}$ Ibnu Taimiyah, Al-Fatawa..., hlm. 260

${ }^{35}$ Secara etimologi tawakal terbentuk dari kata wakala yang berarti menyerahkan, mempercayakan, atau mewakili urusan kepada orang lain. Lihat: A.W. Munawwir, Kamu Al Munawwir Arab-Indonesia, (Surabaya: Pustaka Progressif, 1997) hlm. 1579.

Namun secara terminologi tawakkal ialah penyerahan segala perkara, ikhtiar, dan usaha yag dilakukan kepada Allah SWT, serta berserah diri sepenuhnya kepada-Nya untuk mendapatkan kemaslahatan atau menolak kemudharatan. Dalam al Qur'an kata tawakeal dan yang seakar dengannya diulang sebanyak 70 kali dalam 31 surah, diantaran: QS. al Imaran [3]: 159 dan 173, al Nisa' [4]: 81, Hud [11: 123, al Furqan [25]:58, al Naml [27]: 79 dan lainnya. Lihat; Ensiklopedi Hukum Islam, tentang penjelasan tawakal pada abjad huruf (T).

36Penjelasan lengkap Imam al Ghazali ini dapat dilihat dalam kitab Ibya 'Ulumuddin, pada Bab al Tawakkal. 
tindakan yang tidak dibenarkan karena berobat dan memberikan obat diharuskan kepada seseorang yang sakit.

Pertentangan pendapat mengenai status hukum berobat ini bisa diterima akal, karena tidak terdapatnya penjelasan qath'i tentang permasalahan tersebut sehingga memungkinkan banyak muncul penafsiran (intepretable) terhadap satatus hukumnya.Untuk menyelesaikan persoalan mengenai status hukum berobat yang nantinya berimplikasi kepada mengenai hukum euthanasia negatif (pasif) dalam konteks mengetahui kejelasan hukum apakah pelaku tindakan euthanasia negatif (pasif) mewarisi atau tidak, dengan melihat pendapat Yusuf al Qardhawi yang menytakan bahwa berobat menjadi mustahab bahkan wajib apabila penderita bisa diharapkan sembuhnya, atau dengan berobat itu si sakit sembuh atau sekurang-kurangnya bisa meringankan sakitnya.

Bila tidak ada harapan bagi si penderita sembuh lagi, sesuai dengan hukum sunnatullah sebab-akibat yang diketahui dan dimengerti oleh para ahlinya (dokter) maka tidak akan ada seorang pun yang mengatakan berobat mustahab atau wajib. Apabila si sakit diberi berbagai macam cara pengobatan, atau menggunakan alat pernapasan buatan dan lainnya sesuai dengan penemuan ilmu kedokteran modern, dalam waktu yang cukup lama, tetapi penyakitnya tetap saja tidak ada perubahan, maka melanjutkan pengobatan itu tidak mustahab atau wajib, bahkan mungkin sebaliknya, tidak mengobatinya yang wajib atau mustahab. ${ }^{37}$

Pendapat Yusuf al Qardhawi di atas sangat menarik sebagai pijakan dalam memberikan penjelasan pelaku euthanasia negatif (pasif), apakah bisa mewarisi harta warisan orang yang dilakukan tindakan euthanasia negatif (pasif) terhadapnya.

Tindakan ahli waris yang tidak memberikan atau mengusahakan obat terhadap si sakit, padahal keluarga (ahli waris) sanggup dan memiliki kemampaun untuk mengobatinya, dan secara ilmu kesehatan (menurut dokter) bila diobati dapat mengurangi atau meringankan sakit si pasien, kemudian si sakit menemui kematiannya, maka menurut hemat penulis, ahli warisnya telah melakukan tindakan pembunuhan dengan mengambil manfaat dari sakitnya si pasien. Dengan demikian ahli warinsya tidak berhak mewarisi harta dari orang yang dibiarkannya mati karena sengaja tidak diobatinya.

Namun, bila ahli waris tidak memiliki kesanggupan untuk mengobati, karena besarnya biaya pengobatan, padahal menurut diagnosa dokter ia bisa diobati, atau karena memang tidak adanya obat yang dapat menyembuhkannya, maka dalam tataran seperti ini keluarga (ahli warisnya) tetap bisa mendapatkan harta warisan dari orang yang mati tersebut, sebab tidak termasuk ke dalam kategori pembunuhan yang disebut dalam hadis Nabi terdahulu.

Adapun mengenai sakit si pasien yang tidak diharapkan sembuhnya padahal telah diberi berbagai macam cara pengobatan, atau menggunakan alat 
Al-Fikra: Jurnal Ilmiah Keislaman, Vol. 5, No. 1, Januari-Juni 2006

pernapasan buatan dan lainnya sesuai dengan penemuan ilmu kedokteran modern, dalam waktu yang cukup lama, tetapi penyakitnya tetap saja tidak ada perubahannya, maka keluarga (ahli waris) tetap bisa menerima harta warisan dan keluarganya yang meninggal tersebut karena juga tidak termasuk kedalam kelompok pembunuhan yang terhalang mendapat warisan.

\section{Kesimpulan}

Pelaku euthanasia positif (aktif) terhalang mendapatkan warisan secara syara', karena termasuk ke dalam kecaman hadis Nabi yang menyebutkan: Seorang pembunub tidak mendapatkan harta warisan dari orang yang dibunubnya.

Sedangkan ahli waris yang melakukan tindakan euthanasia negatif (pasif) dikategorikan kepada dua macam; pertama, bila ahli waris atau keluarga tidak memiliki biaya atau kemampuan untuk mengobati sang pasien, padahal secara medis bisa diobati, atau ahli waris memiliki biaya tapi si pasien memang tidak bisa diobati lagi karena parahnya penyakit yang ia derita, kemudian si pasien menemui ajalnya, tidak terhalang mewarisi harta dari orang yang meninggal dunia tersebut, sebab tidak termasuk kedalam kategori pembunuhan; kedua, bila ahli waris atau keluarga memiliki kemampuan biaya untuk mengobati si sakit, dan secara medis bisa diobati dan sembuh, namun ahli waris dan keluarga tidak melakukan pengobatan terhadapnya, kemudian si sakit menemui ajalnya, maka tindakan seperti ini juga termasuk ke dalam pembunuhan disengaja, dan terhalang mendapatkan warisan. Wallabu A'lam.

\section{Bibliografi}

Akbar, Ali, Euthanasia Dilihat dari Hukum Islam, (Panji Masyarakat No. 542 th. XXVI, 21 Desember, 1984).

Arifin, Syamsul, Menurut Pandangan Islam; Euthanasia Dilarang, Kiblat No. 18 th XXVII 1 Pebruari, 1981).

Bek, Hudari, Tarikh al Tasyri' al Islam, (alih bahasa: Muhammad Zuhri, (Indonesia: Daar al Ikhya, 1989)

Bukhari, Abu Abdullah Muhammad bin Ismail al, Sahih al Bukhari, juz 8, (Beirut: Daar al Fikr, 1401 H/1981 M)

Colsen, Noel J., Confilc and Tension in Islamic Juridpridansie, (Cicago: The University Cicagi Press, 1969)

Departemen Agama RI, al Qur'an dan Terjemahan, (Jakarta: Depag RI)

Departemen Pendidikan dan Kebudayaan, Kamus Besar Bahasa Indonesia, (Jakarta: Balai Pustaka, 1989)

Ensiklopedi Hukum Islam, (Jakarta: Ikhtiar Baru Van Hoeve, 1994),

Fatchurrahman, Ilmu Waris, (Bandung: Alma'arif, 1971) 
Al-Fikra: Jurnal Ilmiah Keislaman, Vol. 5, No. 1, Januari-Juni 2006

Hassan, M. Ali, Masail Fiqhiyyah al- Haditsah: pada Masalah-Masalah Kontemporer Hukum Islam, (Jakarta: PT. Raja Grafindo Persada, 1998)

Ibnu Qadamah, al Mugniy, juz. VI (Mesir: Daar al Qutb, tt)

Ibnu Rusyd, Bidayah al Mujtahid, (Semarang : al Syifa)

Ibnu Taimiyyah, Al Fatawa al Kubra, juz. 4, (Kairo: Daar al Ilmiyah, tt)

Jaziri, Abdurrahman al, Kitab al Fiqh 'ala al Mazahib al Arba'ah, (Mesir: al Makhtabah al Tijarriyat al Kubra, 1969)

Karmadi, Petrus Yoyo, Euthanasia dalam Perspektif Hak Azasi Manusia, (Yogyakarta: Media Presindo, 2001)

Khalaf, Abdul Wahab, Ilmu Ushul al Fiqh, (Mesir: Daar al Qalam, 1978)

Khatib, Muhammad Syarbin al, Muhni al Muhtaj, (Kairo : Mustafa al Baby al Halaby, 1995)

Masbukin, Imam, Qawa'id al- Fiqhiyyah, (Jakarta: PT. Raja Frafindo Persada, 2001)

Mahmud, Tahir, Family Law Reform in the Muslim World, (Bombai: Tripathi, 1972)

Munawwir, A.W. Kamus Al Munawwir Arab-Indonesia, (Surabaya: Pustaka Progressif, 1997)

Muslim, Sahih Muslim, juz 2 (Jakarta: Daur Ihya al Kutub al Arabiyah, tt)

Nawawi, Imam, al Tafsir al Munir li Ma'alim al Tanzil, (Semarang: Usaha Keluarga, $\mathrm{tt}$ )

Prodjodikoro, Wirjono, Hukum Warisan di Indonesia, (Bandung: Sumor, 1983)

Qardawi, Yusuf al, Fatwa-Fatwa Kontemporer, Jilid II, (Jakarta: Gema Insani Pers, 1995)

, fi Fiqhi Aulawiyyat: Dirasah Jadidah Dhau'i al Qur'ani wa al Sunnati, alih bahasa: Nurhakim (Jakarta: Gema Insani Perss, 1417 $\mathrm{H} / 1996 \mathrm{M})$

Bulan Bintang, 1995)

Rafiq, Ahmad, Hukum Islam di Indonesia, (Jakarta : Raja Garafindo press, 1998)

Sabiq, Sayyid, Fiqhu al Sunnah, (Beirut: Daar al Fikr, 1983 H/1403 M)

Sabuni, Muhammad Ali al, al Mawaris fi al Syariah al Islamiyah fi Dau al Kitab al Sunnah, (Mekkah: Alam al Kutub, 1305H/1985M) 
Al-Fikra: Jurnal Ilmiah Keislaman, Vol. 5, No. 1, Januari-Juni 2006

San'any, Subul al Salam, (Bandung: dahlan, tt)

Sayis, Muhammad Ali al, Pertumbuhan dan Perkembangan Hukum Fiqh, terj. ( Jakarta: Rja Grafindo persada, 1995).

Shiddieqy, T.M. Hasby ash, Fiqh Mawaris, (Yogyakarta: Mudah, tt)

Shihab, M. Quraish, Membumikan al- Qur'an: Fungsi dan Peran Wahyu dalam Kehidupan Manusia, (Bandung: Mizan, 1994) .

, Wawasan al- Qur'an: Tafsir Maudlui atas Pelbagai Persoalan Ummat, (Bandung: Mizan, 1996)

Syafii, Muhammad bin Idris, al Umm, (Mesir: Dar al Syuaib, 1968

Syaltut, Mahmud, al Islam Akidah wa al Syariah (Mesir: Daar Qalam, 1996) , al Fatawa, (Mesir: Daar al Qalam, tt)

Syaripudin, Amir, Pembaharuan Pemikiran dalam Hukum Islam, (Padang : Angkasa Raya, 1993)

Syatibi, Abu Ishak al, al- Muwafaqat fi al- Ushul Syar'i, Juz II, (Maktabah Tajariyah al- Kubra, tt)

Yahya, Mukhtar dan Fatchurrahman, Dasar-dasar Pembinaan Hukum Islam, (Bandung: Al Ma'arif, 1986)

Yanggo, Huzaimah T., Masail Fiqhiyyah, dalam Edisi Kajian Hukum Islam Kontemporer, (Bandung: Angkasa, 2005)

Zuhaili, Wahbah al, al- Dharurah al- Syari'ah Muwaranah Ma,a al- Qanun al- Wadh'I, (Pustaka al- Faraby, tt)

Zuhdi, Masyfuk, Pengantar Ilmu Hadits, (Malang: PT. Bina Ilmu, 1985) 